\title{
USE OF ELECTRONIC AND PRINTED INFORMATION BY THE FACULTY MEMBERS OF ALLOPATHY AND AYURVEDA COLLEGES IN KERALA: A COMPARATIVE STUDY
}

\author{
Dr. P. M. Prakasan \\ Professional Assistant Gr.I, Department of Botany, \\ University of Calicut, Malappuram, Kerala, India
}

\begin{abstract}
This study aims to conduct a comparative analysis of the use of various types of printed and electronic information by the faculty members of Allopathy and Ayurveda colleges in Kerala. For this purpose a questionnaire based on quantitative study was conducted among the faculty members of both medical systems. Stratified sampling method was applied to this study. Three Medical Colleges and three Ayurveda Colleges in Kerala under Government system have been taken into consideration. Gender and designation wise analysis also conducted. It is clear from the findings and hypothesis tested that there exists significant difference between Allopathy and Ayurveda college faculty members in the use of electronic and printed information.
\end{abstract}

Key words: Information use, Information needs, Faculty members, Printed information, Electronic information, Allopathy colleges, Ayurveda colleges, Kerala

Cite this Article: Dr. P. M. Prakasan, Use of Electronic and Printed Information by the Faculty Members of Allopathy and Ayurveda Colleges in Kerala: A Comparative Study, International Journal of Library \& Information Science, 8(3), 2019, pp. 50-60. http://www.iaeme.com/IJLIS/issues.asp?JType=IJLIS\&VType=8\&IType=3

\section{INTRODUCTION}

In the era of telecommunication technology and social networking, the information explosion and transfer of information is taking place in a massive amount. The availability of information sources and channels are very plenty. This results some positive and negative effects. The positive effect is that there is a chance to get right information to right users at right time with least coast and minimum effort. At the same time there comes information overload and under utilization of information.

This study focuses on the use of various types of electronic and printed information by the faculty members in medical science institutions in Kerala. For this purpose the faculty members of Ayurveda and Allopathy colleges under Government sector were selected and conducted a comparative study. The information professionals and teaching community 
should aware the importance of information and its use. The utilization process of scientific literature is one of the less understood phases of scientific communication. So study aims at understanding the methodology of use of electronic and printed information by the faculty members in medical science institutions is significant.

\section{OBJECTIVES OF THE STUDY}

The main purpose of the study is to conduct a comparative analysis of the use of different types of electronic and printed information by the faculty members of Medical Colleges and Ayurveda Colleges of Kerala State.

\section{HYPOTHESIS OF THE STUDY}

The hypothesis of the study is given below:

'There is significant difference between Allopathy and Ayurveda college faculty members in the use of various types of electronic and printed information'.

\section{METHODOLOGY}

Following methods were adopted for this study:

Sampling Methods: Stratified sampling method was applied to this study. For this study, three Medical Colleges and three Ayurveda Colleges in Kerala under Government sector have been taken into consideration. These colleges were selected on the regional basis (South Kerala, Central Kerala and North Kerala). The population of the study consists of all the faculty members in the selected Government Medical and Ayurveda Colleges in Kerala. The total population of the selected Medical Colleges is 929 and Ayurveda Colleges is 179 faculty members respectively.

Sample Size: The sample size is selected based on the formula of National Education Association (1960) and table introduced by Krejcie and Morgan (1970). This is an effective method of determine sample size needed to be representative of a given population. In their paper they mentioned the formula of determine sample size which was published under the title 'Small-Sample Technique'. The formula was $s=\chi^{2} N P(1-P) \div d^{2}(N-1)+\chi^{2} P(1-P)$.

According to this table the sample size of the given population of Government Medical Colleges $(\mathrm{N}=929)$ is 273 faculty members. Similarly the sample size selected from the population of Government Ayurveda Colleges $(\mathrm{N}=179)$ is 123 teachers. In order to get equal representation of the faculty members of selected colleges, the sample size is divided into three equal units of each medical system. The sample size of Government Medical Colleges (273) is divided into three units, ie. 91 faculty members were from each of the Trivandrum, Trissur and Kozhikode Medical Colleges. Similarly 41 faculty member were selected randomly from each of the Trivandrum, Thrippunnithura and Kannur Ayurveda Colleges.

Questionnaire: Here in this study questionnaire is the main tool of data collection. A questionnaire is a written list of questions, the answers to which are recorded by respondents. The investigator directly visited all the selected colleges of the study and distributed 525 questionnaires among the faculty members. Most of them responded positively by filling up and returning the same.

\section{REVIEW OF RELATED LITERATURE}

Information seeking behaviour is one of the important key concepts of user studies which cover various facets like information, needs, use, access pattern, behaviour in different environment, etc. Till the early second half of 20th century, the study of information needs 
and uses were very limited. According to Wilson (1999), the history of information behaviour dated back to the Royal Society Scientific Information Conference of 1948, where there were some papers that presented in the conference on the different areas of information behavior. Since the Royal Society Conference there has been a gigantic growth in the literature that addressed information needs and information seeking behavior different user communities. In 2006, Case cited around 1100 relevant titles related with information behavior. The accessibility, availability, credibility and accuracy of information sources may have significant impact on the users' information behavior. Wilson (1997), in his article argued for the direct access to the information sources.

Prakasan (2013) reviews the scholarly literature published on the topic information needs and use of healthcare providers around the world. The papers related to medical faculty members, general practitioners, medical students, nursing practitioners, family physicians, health workers, etc. were reviewed. For this purpose literature over 44 years were collected. Prakasan (2013) presented a paper in the National Conference on e-resources and e-learning conducted by the Department of Library and Information Science, University of Calicut. A collection of databases, e-journals, e-books, electronic theses and dissertations, digital libraries, etc. were collected and presented.

A study by Sylla et al. (2012) tried to identify the information needs, information sources, strategies, and barriers to accessing, sharing, and using health information in family planning and reproductive health in Senegal, Africa. Through this study it was found that a persistent need for paper-based information exists, and many health personnel prefer interpersonal communication as a method for information sharing, knowledge synthesis, and learning. Perzeski (2012) conducted a study to evaluate the information-seeking behaviour of pediatric physicians. This questionnaire survey studied the types and frequency of information that podiatric physicians need, various information resources used by podiatrists and the barriers they encounter during information seeking. Bernard et al. (2012) conducted a study on the internet use among French general practitioners, with the background information that the internet is a relevant but underused tool to seek medical information. The study tried to identify the barriers to accessing internet and also the factors that facilitate its use. The study was performed through a cross-sectional survey using an online questionnaire. Results showed that majority of the respondents who used the internet were youngsters, having internet training and having internet access at the work place. The study provided better insights into the obstacles to Internet use by pointing out the barriers. The results also showed that internet has not replaced the traditional sources of medical information.

The objectives of the study undertaken by Melssen (2011) were to determine the information needs, information-seeking strategies and skill levels of hospital clinicians. A questionnaire survey was conducted among two public, medium-sized teaching hospitals (200-250 beds) in Ireland. Results showed that $90 \%$ of the clinicians frequently required information on the latest research on a specific topic, treatment or patient problem. The study revealed that $60 \%$ prefer electronic resources rather than print resources. Print sources consulted are textbooks and journals, the internet, personal colleagues, and databases. Evidence-based resources such as the Cochrane Collaboration are used less frequently than resources such as Medline and Google. Lai and Nalliah (2010), at the International Medical University, Malaysia, through self-administered questionnaires, conducted a survey among medical students with the objectives of understanding the preferred sources of clinical information, online search frequencies, and estimated time to retrieve an abstract. Sixty percent of the respondents indicated that they preferred to first consult another individual (colleagues, lecturers, and hospital staff) for meeting their clinical queries. The frequency of searching PubMed is more than three times per week and more often accessed journals than 
Use of Electronic and Printed Information by the Faculty Members of Allopathy and Ayurveda Colleges in Kerala: A Comparative Study

databases. Forty eight percent of the respondents took 30 minutes or less to trace an abstract of interest.

A study was conducted by Callinan et al. (2010) among the staff in a specialist palliative and gerontological care centre in Mid-West Ireland. A web-based questionnaire was circulated by e-mail supplemented with printed copies. Eighty-three per cent of the respondents indicated that they did not have access to online databases. Results also showed that afternoons are more convenient for visiting the library. Results from such studies can be used to plan the development and organization of the library with a better insight of users' needs to utilise resources more effectively. A study by Haines et al. (2010) examined the information-seeking behavior of basic science researchers at a university medical school through a qualitative study using semi-structured interviews. The study found that the basic science researchers used a variety of information resources ranging from popular internet search engines to highly technical databases. They made little use of traditional library services and did not find the library resources or services as very essential to their work. The study concluded with the suggestion that to maximize the use of library resources, resources must be made accessible through website.

Hider et al. (2009) carried out a postal survey to assess the information seeking behaviour and information needs of a wide range of hospital-based staff including medical, dental and allied health professionals in a large organization serving 5,00,000 people in the centre of the South Island of New Zealand. Questions in the survey asked staff as to how often they consulted textbooks or papers, experts, coworkers, search engines, and library resources to find information. The questions focused on some internet-based resources provided by the library, such as UpToDate, PubMed, Embase, Google, and Google scholar. The study revealed that with the increasing amount of medical information being placed on the internet, professionals use Google as a quick way to access journals and even as a portal to MEDLINE, instead of using traditional library resources. The findings suggest that a large number of staff use and highly value internet-based resources for clinical information seeking.

Prakasan and Humayoon Kabir (2013) made a questionnaire based study on information needs and use pattern of the faculty members of Government Medical and Ayurveda Colleges in South Kerala. The main objective of the study was to conduct a comparative study between Allopathy and Ayurveda college teachers. The result of the study reveals that the medical community needs different types of formal and informal sources to perform well in their profession. Sulemani and Katsekpor (2007) reported the results of a survey undertaken to analyze the access and use of electronic information resources by the health sciences faculty members at the College of Health Sciences of the University of Ghana Medical School. The results showed that the faculty preferred to use electronic databases and full text journals in place of traditional print indexes, abstracts, and hard copy publications. From the findings of the study, it seems conclusive that access to the Internet by faculty has had an impact on their information seeking behaviour.

The study by Curtis and Weller (1993) investigated information-seeking behaviour, including use of major bibliographic tools by medical, pharmacy, nursing, and science faculty at the University of Illinois at Chicago. The study assessed the impact of availability of locally mounted databases, determined needs for modification of instructional programs and also identified the need for promotional materials. Results reflected that over $70 \%$ of the faculty from the colleges of medicine, pharmacy, and nursing used Index Medicus or MEDLINE. Colleges exhibited significant differences in use of Current Contents, PsycLIT, Education Resources Information Centre (ERIC), Cumulative Index to Nursing and Allied Health Literature (CINAHL), Chemical Abstracts, and Science Citation Index. 


\section{ANALYSIS AND INTERPRETATION OF DATA}

The detailed statistical analysis and interpretation of data collected from the faculty members of Government Medical and Ayurveda colleges in Kerala is given below.

Use of Various Types of Electronic Information

There are so many occasions that the faculty members use different types of electronic information. The use of information may be to assist with diagnosis, treatment options, drug information, patient care, continuing education, experiment and research, teaching and guiding, etc. Table 1 depicts the picture of the frequency of use arises on different situations.

Table 1 Use of Various Types of Electronic Information

\begin{tabular}{|c|c|c|c|c|c|c|c|c|}
\hline \multirow[b]{2}{*}{ Type of Information } & \multicolumn{4}{|c|}{ Allopathy } & \multicolumn{4}{|c|}{ Ayurveda } \\
\hline & & 巳ี & $\sum_{i}^{\infty}$ & $\begin{array}{l}\bar{d} \\
\dot{z} \\
\bar{z}\end{array}$ & 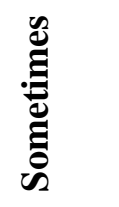 & 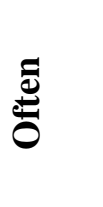 & $\frac{n}{2}$ & $\frac{\grave{d}}{\sum^{2}}$ \\
\hline $\begin{array}{l}\text { Information to assist with } \\
\text { diagnosis }\end{array}$ & 51.28 & 19.78 & 28.94 & 0.00 & 61.74 & 8.70 & 0.00 & 29.57 \\
\hline $\begin{array}{l}\text { Treatment options for } \\
\text { diseases }\end{array}$ & 8.06 & 43.22 & 48.72 & 0.00 & 87.60 & 0.00 & 0.00 & 12.40 \\
\hline $\begin{array}{l}\text { Information on diseases } \\
\text { and syndromes }\end{array}$ & 21.27 & 41.79 & 36.94 & 0.00 & 71.54 & 3.25 & 0.00 & 25.20 \\
\hline $\begin{array}{l}\text { Drug information } \\
\text { (including new drugs ) }\end{array}$ & 15.30 & 36.57 & 48.13 & 0.00 & 50.00 & 16.39 & 3.28 & 30.33 \\
\hline $\begin{array}{l}\text { Information to the patient- } \\
\text { care }\end{array}$ & 42.12 & 26.01 & 16.12 & 15.75 & 55.74 & 0.00 & 0.00 & 44.26 \\
\hline $\begin{array}{l}\text { Continuing professional } \\
\text { development }\end{array}$ & 33.21 & 16.61 & 45.39 & 4.80 & 36.13 & 27.73 & 13.45 & 22.69 \\
\hline Experiment and research & 29.32 & 48.87 & 21.80 & 0.00 & 73.77 & 4.10 & 3.28 & 18.85 \\
\hline Teaching and guiding & 7.01 & 40.59 & 52.40 & 0.00 & 42.28 & 5.69 & 28.46 & 23.58 \\
\hline $\begin{array}{l}\text { Current trends and } \\
\text { developments }\end{array}$ & 6.77 & 29.70 & 63.53 & 0.00 & 68.60 & 7.44 & 9.09 & 14.88 \\
\hline
\end{tabular}

Among the respondents, $63.53 \%$ of Medical faculty members 'always' prefer electronic information to know the current trends and developments, whereas only $9.09 \%$ of Ayurveda faculty members 'always' use electronic information for the same purpose. Around half (48.87\%) of the Allopathy college teachers 'often' access to electronic information for experiment and research, whereas only $4.10 \%$ of Ayurveda faculty members 'often' prefer electronic information for the same purpose.

Out of the respondents of Allopathy colleges, 51.28\% teachers 'sometimes' use electronic information to assist with diagnosis, but $61.74 \%$ of Ayurveda college faculty members 'sometimes' access to assist with diagnosis.

It is noticed that only $15.75 \%$ of Allopathy teachers 'never' prefer electronic information to the patient care, but $44.26 \%$ Ayurveda teachers 'never' access to electronic information for patient care.

There are different situations that the faculty members frequently accessing electronic information. Data and result of the comparative analysis of electronically access information in various types in different situations between Allopathy and Ayurveda college faculty members is presented in Table 2. 
Use of Electronic and Printed Information by the Faculty Members of Allopathy and Ayurveda Colleges in Kerala: A Comparative Study

Table 2 Significant Difference of the Use of Various Types of Electronic Information

\begin{tabular}{lccccc}
\hline \multicolumn{1}{c}{ Group } & $\begin{array}{c}\text { No. of Samples } \\
(\mathbf{N})\end{array}$ & Mean & S.D. & 't'-value & Significance \\
\hline $\begin{array}{l}\text { Allopathy } \\
\text { Ayurveda }\end{array}$ & 273 & 27.73 & 3.17 & \multirow{2}{*}{34.862} & Significant \\
\cline { 2 - 5 }
\end{tabular}

The scores of types of electronically accessed information obtained for the Allopathy teachers is 27.73 with SD 3.17 and that of Ayurveda teachers is 17.36 with SD 2.51. The table also reveals that the type of information access from electronic sources score is greater for Allopathy faculty members than Ayurveda faculty members.

There exists significant difference between Allopathy and Ayurveda faculty members with regard to the types of information access electronically, since the calculated ' $t$ ' value (34.86) is greater than table value (1.96) at 0.05 level of significance.

The comparison of use of various types of electronic information between Allopathy and Ayurveda faculty members is done separately for male and female samples and it is presented in Table 3.

Table 3 Gender-wise Distribution of Electronic Information Access

\begin{tabular}{|c|c|c|c|c|c|c|}
\hline Gender & College & $\begin{array}{c}\text { No. of } \\
\text { Samples (N) }\end{array}$ & Mean & S.D. & 't'-value & Significance \\
\hline \multirow[t]{2}{*}{ Male } & Allopathy & 146 & 27.73 & 3.24 & \multirow{2}{*}{24.382} & \multirow{2}{*}{ Significant } \\
\hline & Ayurveda & 60 & 17.36 & 2.55 & & \\
\hline \multirow[t]{2}{*}{ Female } & Allopathy & 127 & 27.73 & 3.10 & \multirow{2}{*}{24.762} & \multirow{2}{*}{ Significant } \\
\hline & Ayurveda & 63 & 17.36 & 2.50 & & \\
\hline
\end{tabular}

The result given in Table 3 reveals the types of information access electronically and the score obtained for both male and female faculty members of Medical colleges is greater than Ayurveda colleges.

There exists significant difference between Allopathy and Ayurveda college faculty members, with regard to the types of information access electronically. The calculated ' $t$ ' value obtained by male (24.38) and female (24.76) faculty members is greater than the table value (1.96) at 0.05 level of significance.

The comparison of use of various types of electronic information between Allopathy and Ayurveda faculty members is done separately for Lecturer, Assistant Professor, Associate Professor and Professor samples and presented in Table 4.

Table 4 Designation-wise Distribution of Electronic Information Access

\begin{tabular}{|c|c|c|c|c|c|c|}
\hline Designation & College & $\begin{array}{c}\text { No. of } \\
\text { Samples (N) }\end{array}$ & Mean & S.D. & 't'-value & Significance \\
\hline \multirow[t]{2}{*}{ Lecturer } & Allopathy & 47 & 27.48 & 2.94 & \multirow{2}{*}{18.642} & \multirow{2}{*}{ Significant } \\
\hline & Ayurveda & 31 & 17.45 & 1.80 & & \\
\hline Assistant & Allopathy & 110 & 27.79 & 3.01 & \multirow{2}{*}{16.136} & \multirow{2}{*}{ Significant } \\
\hline Professor & Ayurveda & 28 & 18.07 & 2.80 & & \\
\hline Associate & Allopathy & 97 & 28.08 & 3.29 & \multirow{2}{*}{19.559} & \multirow{2}{*}{ Significant } \\
\hline Professor & Ayurveda & 34 & 17.50 & 2.47 & & \\
\hline \multirow[t]{2}{*}{ Professor } & Allopathy & 19 & 26.21 & 3.72 & \multirow{2}{*}{9.827} & \multirow{2}{*}{ Significant } \\
\hline & Ayurveda & 30 & 16.46 & 2.76 & & \\
\hline
\end{tabular}


Table 4 reveals that the types of information access electronically score obtained for Lecturer, Assistant Professor, Associate Professor and Professor of Allopathy colleges are higher than Ayurveda colleges.

There exists significant difference between Allopathy and Ayurveda college teachers, with regard to the types of information access electronically. The calculated ' $t$ ' value obtained by Lecturer (18.64), Assistant Professor (16.13), Associate Professor (19.55) and Professor (9.82) are greater than the table value (1.96) at 0.05 level of significance.

Use of Various Types of Printed Information

Printed forms of information sources are the major information sources that the faculty members frequently depend for getting information for various purposes.

Table 5 Use of Various Types of Printed Information

\begin{tabular}{|c|c|c|c|c|c|c|c|c|}
\hline \multirow[b]{2}{*}{ Type of Information } & \multicolumn{4}{|c|}{ Allopathy } & \multicolumn{4}{|c|}{ Ayurveda } \\
\hline & 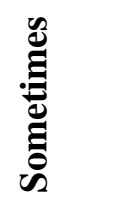 & $\stackrel{\bar{d}}{0}_{0}^{\pi}$ & $\frac{n}{2}$ & $\begin{array}{l}\dot{\bar{d}} \\
\text { ż }\end{array}$ & 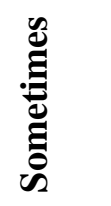 & $\stackrel{\Xi}{0}$ & $\sum_{i}^{\infty}$ & $\begin{array}{l}\bar{d} \\
z \\
z\end{array}$ \\
\hline $\begin{array}{l}\text { Information to assist } \\
\text { with diagnosis }\end{array}$ & 43.45 & 19.48 & 37.08 & 0.00 & 15.25 & 18.64 & 53.39 & 12.71 \\
\hline $\begin{array}{l}\text { Treatment options for } \\
\text { diseases }\end{array}$ & 50.00 & 30.88 & 19.12 & 0.00 & 13.93 & 31.97 & 52.46 & 1.64 \\
\hline $\begin{array}{l}\text { Information on diseases } \\
\text { and syndromes }\end{array}$ & 47.99 & 20.88 & 31.14 & 0.00 & 36.59 & 18.70 & 44.72 & 0.00 \\
\hline $\begin{array}{l}\text { Drug information } \\
\text { (including new drugs ) }\end{array}$ & 37.00 & 20.15 & 42.86 & 0.00 & 27.73 & 22.69 & 49.58 & 0.00 \\
\hline $\begin{array}{l}\text { Information to the } \\
\text { patient-care }\end{array}$ & 51.72 & 27.59 & 20.69 & 0.00 & 3.28 & 22.13 & 56.56 & 18.03 \\
\hline $\begin{array}{l}\text { Continuing professional } \\
\text { development }\end{array}$ & 22.71 & 16.48 & 57.88 & 2.93 & 34.75 & 14.41 & 29.66 & 21.19 \\
\hline $\begin{array}{l}\text { Experiment and } \\
\text { research }\end{array}$ & 43.46 & 28.85 & 27.69 & 0.00 & 12.30 & 38.52 & 49.18 & 0.00 \\
\hline Teaching and guiding & 51.50 & 13.53 & 34.96 & 0.00 & 14.17 & 20.00 & 65.83 & 0.00 \\
\hline $\begin{array}{l}\text { Current trends and } \\
\text { developments }\end{array}$ & 53.51 & 23.99 & 22.51 & 0.00 & 27.05 & 22.13 & 47.54 & 3.28 \\
\hline
\end{tabular}

Among the respondents, $57.88 \%$ of Medical faculty members 'always' access to printed information for professional development, whereas only $29.66 \%$ of Ayurveda faculty members 'always' use printed information for the same purpose.

It is found that $30.88 \%$ of the Allopathy college teachers 'often' prefer printed information for the treatment options for diseases, whereas $31.97 \%$ of Ayurveda faculty members 'often' access to manual information for the same purpose.

Out of the respondents of Allopathy colleges, $53.51 \%$ of teachers 'sometimes' use printed information to know current trends and developments, but only $27.05 \%$ of Ayurveda college faculty members 'sometimes' prefer it.

It is noticed that only $2.93 \%$ of Allopathy teachers 'never' access to manual information for continuing professional development, but $21.19 \%$ Ayurveda teachers 'never' use manual information for continuing professional development.

The faculty members often need and use types of information related with various activities of teaching, guiding, patient care and practice. Data and result of the comparative 
Use of Electronic and Printed Information by the Faculty Members of Allopathy and Ayurveda Colleges in Kerala: A Comparative Study

analysis of manually access to information in various types in different occasions of Allopathy and Ayurveda college faculty members is presented in Table 6.

Table 6 Significant Difference of the Need of Various Types of Printed Information

\begin{tabular}{|c|c|c|c|c|c|}
\hline Group & $\begin{array}{c}\text { No. of Samples } \\
(\mathbf{N})\end{array}$ & Mean & S.D. & 't'-value & Significance \\
\hline Allopathy & 273 & 25.44 & 5.05 & \multirow{2}{*}{6.189} & \multirow{2}{*}{ Significant } \\
\hline Ayurveda & 123 & 27.97 & 3.00 & & \\
\hline
\end{tabular}

The data given in Table 6 depicts the picture that the various types of information access manually scores obtained for the Allopathy teachers is 25.44 with SD 5.05 and that of Ayurveda teachers is 27.97 with SD 3.00. The analysis also shows that the types of information access from manual sources score is less for Allopathy teachers than Ayurveda teachers.

There exist significant difference between Allopathy and Ayurveda faculty members with regard to the types or information access manually, since the calculated ' $t$ ' value (6.189) is greater than table value (1.96) at 0.05 level of significance.

The comparison of use of various types of printed information between Allopathy and Ayurveda faculty members is done separately for male and female samples and it is presented in Table 7.

Table 7 Gender-wise Distribution of Access to Printed Information

\begin{tabular}{lcccccl}
\hline \multicolumn{1}{c}{ Gender } & College & $\begin{array}{c}\text { No. of } \\
\text { Samples }(\mathbf{N})\end{array}$ & Mean & S.D. & 't'-value & Significance \\
\hline Male & Allopathy & 146 & 25.41 & 5.07 & \multirow{2}{*}{4.532} & Significant \\
& Ayurveda & 60 & 28.03 & 3.06 & \multirow{2}{*}{ Significant } \\
\hline Female & Allopathy & 127 & 25.48 & 5.03 & \multirow{2}{*}{4.183} & \multirow{2}{*}{ Signta } \\
& Ayurveda & 63 & 27.92 & 2.97 & &
\end{tabular}

It is seen from the Table 7 that the types of information access manually score obtained for both male and female faculty members of Medical colleges is less than Ayurveda colleges.

There exists significant difference between Allopathy and Ayurveda college faculty members, with regard to the types of information access manually. The calculated ' $t$ ' value obtained by male (4.532) and female (4.183) faculty members is greater than the table value (1.96) at 0.05 level of significance.

The comparison of use of various types of printed information between Allopathy and Ayurveda faculty members is done separately for Lecturer, Assistant Professor, Associate Professor and Professor samples and presented in Table 8.

Table 8 Designation-wise Distribution of Access to Printed Information

\begin{tabular}{|c|c|c|c|c|c|c|}
\hline Designation & College & $\begin{array}{c}\text { No. of } \\
\text { Samples } \\
(\mathbf{N})\end{array}$ & Mean & S.D. & $\begin{array}{c}\text { 't'- } \\
\text { value }\end{array}$ & Significance \\
\hline \multirow[t]{2}{*}{ Lecturer } & Allopathy & 47 & 27.17 & 4.53 & \multirow{2}{*}{1.659} & \multirow{2}{*}{ Not Significant } \\
\hline & Ayurveda & 31 & 28.54 & 2.80 & & \\
\hline \multirow{2}{*}{$\begin{array}{l}\text { Assistant } \\
\text { Professor }\end{array}$} & Allopathy & 110 & 25.46 & 5.02 & \multirow{2}{*}{2.546} & \multirow{2}{*}{ Significant } \\
\hline & Ayurveda & 28 & 27.28 & 2.81 & & \\
\hline \multirow{2}{*}{$\begin{array}{l}\text { Associate } \\
\text { Professor }\end{array}$} & Allopathy & 97 & 24.81 & 5.17 & \multirow{2}{*}{4.212} & \multirow{2}{*}{ Significant } \\
\hline & Ayurveda & 34 & 28.05 & 3.28 & & \\
\hline \multirow[t]{2}{*}{ Professor } & Allopathy & 19 & 24.31 & 5.08 & \multirow{2}{*}{2.793} & \multirow{2}{*}{ Significant } \\
\hline & Ayurveda & 30 & 27.93 & 3.07 & & \\
\hline
\end{tabular}


The types of information access manually score obtained for Lecturer, Assistant Professor, Associate Professor and Professor of Allopathy colleges are less than Ayurveda colleges as per Table 8.

There exists significant difference between Allopathy and Ayurveda college teachers, except Lecturer, with regard to the types of information access manually. The calculated ' $t$ 'value obtained by Assistant professor (2.546), Associate Professor (4.212) and Professor (2.793) are greater than the table value (1.96) at 0.05 level of significance. But the calculated ' $t$ '-value obtained by Lecturer (1.659) is less than table value (1.96) at 0.05 level of significance.

\section{MAJOR FINDINGS}

On the basis of comparative analysis major findings are listed below:

- Among the respondents, $63.53 \%$ of Medical faculty members 'always' access to electronic information on current trends and developments, whereas only $9.09 \%$ of Ayurveda faculty members 'always' prefer electronic information for the same purpose.

- The Medical college faculty members (48.87\%) 'often' use electronic information for experiment and research, whereas only $4.10 \%$ of Ayurveda faculty members 'often' access electronic information for the same purpose.

- Out of the respondents of Allopathy college 51.28\% 'sometimes' use electronic information to assist with diagnosis, but $61.74 \%$ of Ayurveda college faculty members 'sometimes' access to electronic information to assist with diagnosis.

- It is noticed that only $15.75 \%$ of Allopathy teachers 'never' prefer electronic information to the patient care, but $44.26 \%$ Ayurveda teachers 'never' access to electronic information for patient care.

- It is clear from the analysis that $57.88 \%$ of Allopathy teachers 'always' use printed sources of information for continuing professional development, whereas only 29.66\% of Ayurveda faculty members 'always' use manual information for the same purpose.

- Among the Medical faculty members, $30.88 \%$ 'often' use printed information for finding treatment options for diseases. But $31.97 \%$ of Ayurveda teachers 'often' prefer printed information for the same purpose.

- Out of the total respondents of Allopathy colleges, 53.51\% 'sometimes' access to printed inormation to up to date with current trends and development, but only $27.05 \%$ of Ayurveda college teachers 'sometimes' approach it.

- Allopathy faculty members (2.93\%) 'never' use printed inormation for continuing professional development, but $21.19 \%$ of Ayurveda teachers 'never' prefer manual sources for the continuing professional development.

- The gender and designation wise analysis of data shows that there exists significant difference between Allopathy and Ayurveda college teachers, with regard to the types of information access to electronically or manually.

\section{Testing of Hypothesis}

On the basis of the findings drawn from the study, the tenability of the hypothesis formulated for the study is given below:

The hypothesis states that there is significant difference between Allopathy and Ayurveda college faculty members in the use of electronic and printed information. It is evident from the analysis of the Table 1 to Table 8 that there exist significant difference between Allopathy and Ayurveda college faculty members with regard to the use of electronic and printed information, since the calculated ' $t$ '-values are greater than the table value(1.96) at 0.05 level of significance. Hence the hypothesis of the study is fully substantiated.

Conclusion 
Use of Electronic and Printed Information by the Faculty Members of Allopathy and Ayurveda Colleges in Kerala: A Comparative Study

The ultimate aim of this study was to conduct a comparative analysis of the information use of faculty members of Government Allopathy and Ayurveda colleges in Kerala. For this purpose a questionnaire based quantitative study was conducted among the faculty members of both systems. The collected data were manually coded in the datasheet and analysed with the help of SPSS software. The statistical tests like Chi-square test, ' $t$ ' test, etc. were employed for the analysis. Gender and designation wise analysis also conducted. The tenability of hypothesis was also tested on the basis of major findings. It is clear from the findings and hypotheses tested that there exists significant difference between Allopathy and Ayurveda college faculty members in all aspects of the use of various types of printed and electronic information.

\section{REFERENCES}

[1] Bernard, E. et al. (2012). Internet use for information seeking in clinical practice: a crosssectional survey among French general practitioners. International Journal of Medical Informatics, 81(7), 493-99.

[2] Callinan, J. et al. (2010). Analysis of library associated information needs of staff in a specialist palliative and gerontological care centre in Mid-West Ireland. Health Information and Libraries Journal, 27(4), 86-94.

[3] Case, D. (2006). Looking for information: A survey of research on information seeking, needs, and behaviours. (2nd ed.). San Diego: Academic Press.

[4] Curtis, K.L., \& Weller, A.C. (1993). Information-seeking behavior: a survey of health sciences faculty use of indexes and databases. Bulletin of the Medical Library Association, 81(4), 383-92, Retrieved from https://www.ncbi.nlm.nih.gov/pmc/articles/PMC225821/

[5] Haines, L.L. et al. (2010). Information-seeking behavior of basic science researchers: implications for library services. Journal of Medical Library Association, 98(1), 73-81.

[6] Hider, P.N. et al. (2009). The information-seeking behavior of clinical staff in a large health care organization. Journal of Medical Library Association, 97(1), 47-50.

[7] Krejcie, Robert V., \& Morgan, Daryle W. (1970). Determining sample size for research activities. Educational and Psychological Measurement. 30, 607-610, Retrieved from https://home.kku.ac.th/sompong/guest_speaker/KrejcieandMorgan_article.pdf

[8] Lai, N.M., \& Nalliah, S. (2010). Information-seeking practices of senior medical students: the impact of an evidence-based medicine training programme. Education for Health (Abingdon), 23(1), 151.

[9] Melssen, M.C. (2011). Study of limited value in exploring Irish hospital clinicians' information behaviour and attitudes towards the clinical informationist. Evidence Based Library and Information Practice, 6(4), 149-51.

[10] National Education Association. (1960). Small-sample techniques. The NEA Research Bulletin, 38, 99.

[11] Perzeski, D.M. (2012). Information-seeking behaviors of podiatric physicians. Journal of American Podiatric Medical Association, 102(6), 451-62.

[12] Prakasan P.M., \& Humayoon Kabir S. (2013). Information needs and use pattern of faculty members of Government medical colleges in South Kerala, India: A comparative analysis. Kelpro Bulletin, 17(1), 34-42.

[13] Prakasan P.M. (2013). E-resources for healthcare professionals. Proceedings of the national conference on e-resources and e-learning. Kerala: University of Calicut, 120126. 
[14] Prakasan P.M. (2013). Information needs and use of healthcare professionals: International perspective. DESIDOC Journal of Library \& Information Technology, 33(6), 465-473.

[15] Sulemani, S.B., \& Katsekpor, S.A. (2007). Information seeking behavior of health sciences faculty at the College of Health Sciences, University of Ghana. Information Development, 23(1), 63-70, Retrieved from http://citeseerx.ist.psu.edu/viewdoc/download?doi=10.1.1.977.5322\&rep=rep1\&type=pdf

[16] Sylla, A.H. et al. (2012). Qualitative study of health information needs, flow and use in Senegal. Journal of Health Communication, 17(2), 46-63.

[17] Wilson, T. D. (1997). Information behaviour: An interdisciplinary perspective. Information Processing and Management, 33 (4), 551-572.

[18] Wilson, T. D. (1999). Models in information behaviour research. The Journal of Documentation, 55 (3), 249-270. 